\title{
Impact of Hotel Service Quality on Attracting Tourist and Achieving their Loyalty: A Case Study of Hotel Industry in Kurdistan Region
}

\author{
Dr. Walla Jawdat Ali Al-jaf \\ Assistant Professour \\ Faculty of Humanities and Social Science \\ Department of Management and Economics
University of Koya
Republic of Iraq

\author{
Dr.Younis A.Ahmed \\ Assistant Professour \\ College of Administration and Economics \\ Department of Economics \\ University of Sulaimani \\ Republic of Iraq
}

\author{
Dalia Khalid Faeq \\ Faculty of Humanities and Social Science \\ Department of Management and Economics \\ University of Koya \\ Republic of Iraq
}

\begin{abstract}
The Kurdistan region of Iraq has great potential to attract a large number of tourists. In fact, five-star hotels in the Kurdistan attempts to get greater market share and maximizing hotels profits by attracting more tourists and achieving tourist loyalty, by providing high level and different types of services. The main objective of this study is to find out the impact of service quality on attracting tourists and tourist loyalty in the five-star hotels in Sulaimani province/Kurdistan Region- Iraq. To achieve this objective, the study adopts descriptive analytical method (DAM), and was based on the previous studies and literature review related to the subject of the study. Furthermore, the primary data are collected from a survey conducted during the period from 25/11/2016 to 25/12/2016, on (70) guests who stayed in five-star hotels. In alignment with the research objectives and methodology, this study developed the following hypothesis "there is a strong and significant relationship between the quality of service and attracting tourists and tourist loyalty in five-star hotels". Furthermore, the regression model interpretation ability for all service quality dimensions represented in $\left(R^{2}\right)$ coefficient was 0.85 which indicating that $85 \%$ of changes in attracting tourists and tourist loyalty are interpreted by service quality dimensions. To sum up, a set of necessary recommendations for hotels was formulated to attract more tourists through providing more and high quality of services.
\end{abstract}

Keywords: Service Quality, Attracting Tourist, Tourist Loyalty, Five-Star hotels, Sulaimani Province Kurdistan Region/Iraq.

\section{Introduction}

Tourism is becoming one of the largest global export industries (Burns and Holden 1995). The trend of world markets has changed noticeably from agricultural to service markets (Asian Development Outlook, 2007). The Kurdistan region in Iraq has beautiful cities, the Annaba waters, towering mountains and caverns carrying the story of Iraq since the earliest civilizations, waterfalls, evergreen trees, moderate climate even during sum-

* This article was submitted in July 2018, accepted for publishing in October 2018 and published on December 2020.

(c) Arab Administrative Development Organization- League of Arab States, 2019, pp 323-336،

DOI: 10.21608/aja.2020.131064 
mer, beautiful winters which snow falls on the mountains, and the emergence of green with the beginning of spring (Ministry of Tourism- KRG, 2011). With customer's loyalty, quality in service of hotel sector is an important factor and may lead to the success of the tourism business in north of Iraq. In 2011, National Geographic selected the Kurdistan region of Iraq to be listed among the best tourist attractions in the world Moreover, the New York Times also ranked the north of Iraq among the best tourist attractions in the world for the same year (2011), when the region was ranked 34th among 41 different tourist destinations in the world (Ahmed, 2014).

Achieving high levels of provided hotel's service quality to its guests is one of the most effective ways to ensure attracting supplying hotels with loyal guests in the short term, and will persist to be loyal in the long term. Hotels operators try to focus more on the quality standards for meeting the basic needs and expectations of their guests. Many previous studies indicated that there is a positive relationship between customer perceptions of service quality and his loyalty level, represented by encouraging others to deal with service provider and transfer positive news about him to others, and non-willing to switch to another competitor, which is reflected in consideration service provider as the first choice for shopping and increasing the deal intention with him in the coming period (Al.Bostanji \& Bin Sau'd, 2013). Studies have proved that the cost of attracting new customers(Guests - Tourists) is five times the cost of current customer retention, and also low loss of customers by $5 \%$ leads to increased profits from $25 \%$ to $85 \%$ (Kotler, 2003). Moreover, loyal customer's recommendations lead to new customer's (Guests - Tourists) attraction without bearing any marketing cost by the organization in attracting them, in addition to that loyal customer is willing to pay a higher price against the desired value.

\section{Literature Review and tTheoretical Framework}

\section{Empirical Literature Review}

There are a number of studies have examined the relationship between service quality, tourist attract and tourist loyalty. The three elements are considered as the backbone for efficiency and performance in many hotels. For better understanding, this section provides an overview of the past studies which related this topic.

A (2006) demonstrated that the five service quality dimensions identified in this study were named as "tangibles", "adequacy in service supply", "understanding and caring", "assurance", and "convenience". The result showed that business travellers had the highest expectations for the dimension of "convenience" followed by "assurance", "tangibles", adequacy in service supply", and "understanding and caring". As well as confirmed that the SERVQUAL scale was a very useful tool as a concept, it needed to be adapted for the specific service segments and for the cultural context within which it was used (Kheng et al., 2010) research documented that the improvement in service quality dimensions can enhance customer loyalty of banks in Penang, Malaysia. The emergence of new forms of banking channels such as Internet banking, Automated Teller Machines (ATM), phone banking and also maturing financial market and global competition has forced bankers to explore the importance of customer loyalty. The underlying model of SERVQUAL (Parasuraman. et al., 1988) with five dimensions was used.

Mosahab, R. et al. (2010) revealed that the customer satisfaction plays as a mediator in the effects of service quality on service loyalty as well as in all aspects, customers' expectation, are higher than their perceptions of the Sepah Bank in Tehran, Iran Bank's operation, and in fact the quality of offered services is low. In this study, the service quality standard model has been used for evaluation of service quality, Gremler and Brown (1996) model with some revision was used for evaluating the loyalty, and the instrument offered by Bitner and Hubbert (1994) was used for evaluation of customer satisfaction. Al-Rousan, M. Ramzi \& Mohamed, B (2010) evaluated the service quality as a competitive policy in the present Jordan hotels scenario. The results show that dimensions of service quality such as (empathy, reliability, responsiveness and tangibility) significantly predict customer loyalty. Specifically, among the dimension of tourism service quality, the most significant predictor of customer loyalty is tangibility. Jahanshahi, A. et al. (2011) documented that there are high positive correlation between the constructs of customer service and product quality to 
customer satisfaction and loyalty in the automotive industry in India. Siddiqi, K. O. (2011) showed that all the service quality attributes are positively related to customer satisfaction and customer satisfaction is positively related to customer loyalty in the retail banking settings in Bangladesh.

Abu Elsamen \& alsurideh, (2012) documented that there is a positive relationship between Internal Marketing dimensions and perceived Internal Service Quality in varying magnitude. Service providers are recommended to apply IM strategy in order to enhance perceived ISQ foster better external service quality. Al. Bostanji, G. M. \& Bin Sau'd, I. M.(2013) demonstrated that there is a positive impact of service quality (quick responsiveness, empathy and tangibility) on customer loyalty in five star hotels in Riyadh.

Poku, K. et al. (2013) reveals that customer satisfaction is not based solely on the rankings/classification of the hotels in Ghana, but on service quality that gives value for money which in turn produces customer loyalty, however, "Tangibility" does not play any significant role in developing customer loyalty for all the hotels because the guests were least satisfied with it and are likely to take it for granted in their quest for change. Khraim Hamza Salim (2013) study showed a significant effect of Airline Image was observed with regard to customers 'behavioral intentions as well as a significant effect of service quality was observed with regard to customers' behavioral in Jordan. Al Bassam, (2013) measured the Service Quality in Internet-Based Services in the Kingdom of Saudi Arabia.The study proposes a revised and modified SERVQUAL model which incorporates several variables that reflects the industry-specific attributes of Internet banking services. A primary data with multiple regression analysis is employed to examine the influence of the adapted determinants on service quality. Focus-group interviews are also conducted as a follow-up to the questionnaire study.

The findings of both fieldworks indicate that reliability, responsiveness, website design, and personalization determine service quality in the Internet banking context. Geronikolas, (2012) reported that the five factors in the hotel industry that are most likely to drive customers away include untrained and perceived rude staff; lack of cleanliness around the premises, in hotel rooms or within its restaurants; the guest's desire to experience new places ("need for change"); price, affordability, and value for money. Overall, hotel food and beverage standards appear as the most important in hotel tangibles and seem to be becoming increasingly significant in creating both a loyal base of satisfied customers and driving dissatisfied customers away. Saleem \& Raja (2014) suggested that high quality of services boost up the customer satisfaction and then afterward this satisfaction will strengthen the customer loyalty(5 and 8) star hotels of Pakistan.

Hossaini, S. et al., (2015)study investigated the effects of Service Performance of Hotel Customers on Quality of Experience and Brand Loyalty in Iran. The present study obtained data from (302) international and local customers in four and five Star hotels in five major cities in Iran. This study will significantly contribute to the Iranian tourism market in seeking improvement towards the effectiveness of hotel customers and loyalty in Iran. Bagdare, Shilpa (2016) suggested that employee performance can be grouped into five factors, namely (reliability, customer orientation, responsiveness, respect, and relationship orientation). It is also found that there is a significant positive effect of employee performance on customer loyalty.

Jasinskas Edmundas, et al. (2016) Measured the Impact of the quality of hotel service quality on the loyalty of customers. In this study the original created methodology SERQUALOYL is presented. The results of study have revealed that the conformity of expected quality with the quality experienced has a significant influence on the customer loyalty. The hotels, in order to increase the competitive ability and to obtain a higher number of loyal customers, should firstly make the expectations of customers coincide with the offered service quality.

From above present, despite differences from activity to other, but we can conclude that the service quality has high significant relation with tourist attracts and tourist loyalty. Furthermore, current study conf tributes to the body of knowledge, because this study on hotel industry in Kurdistan region of Iraq and no current international academic journals have published papers on the same subject. 


\section{Theoretical Framework}

The main issue of the theoretical framework is to understand the basic fundamentals of the study. Conclusion of the study would not be possible without presenting the theoretical framework. Thus, current study tries to present main framework of the study as follow:

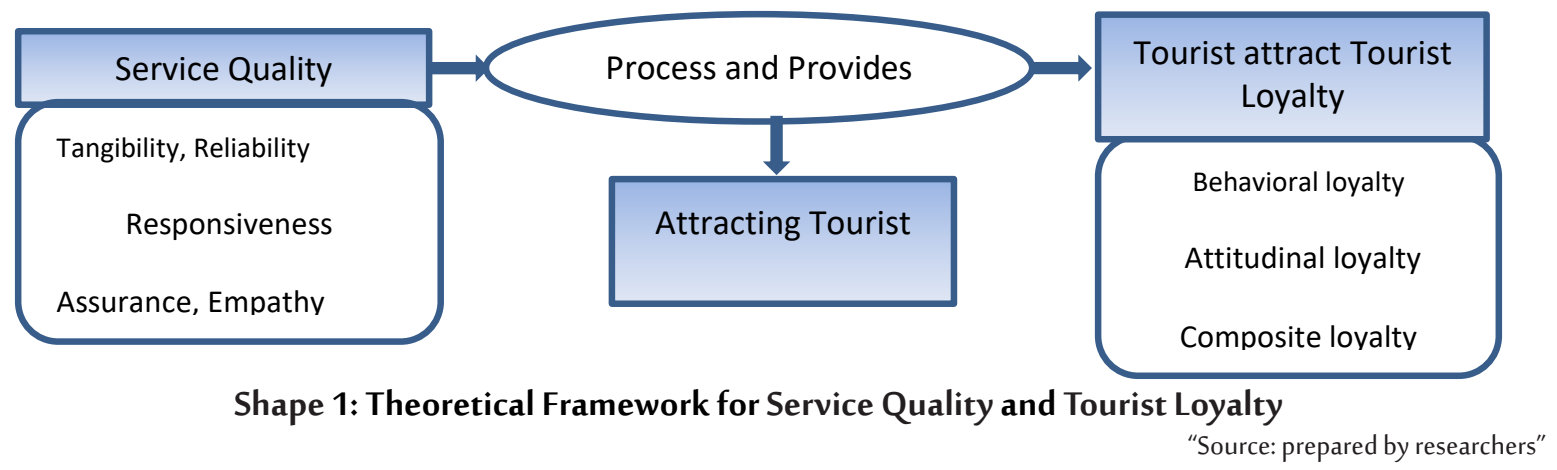

Shape (1) shows the relationship among service quality, tourist attracting and tourist loyalty. The independent variable in this study is "service quality" that represented by five dimensions (tangibility, reliability, responsiveness, assurance, empathy). On the other hand, the dependent variable is "tourist loyalty".

Service: Service is activity or perceives intangible benefit to customer in a specific time.

\begin{tabular}{cc}
\hline $\begin{array}{c}\text { Authors } \\
2000\end{array}$ & Definition \\
\hline $\begin{array}{c}\text { Zeithaml, V. A., } \\
\text { Gronroos, C. , } 2000\end{array}$ & $\begin{array}{r}\text { Service is a process consisting of a series of more or less intangible activities that normally, but not } \\
\text { necessarily always, takes place in interactions between the customer and service employees. }\end{array}$ \\
\hline $\begin{array}{r}\text { Kotler \& Armstrong, } \\
2004\end{array}$ & $\begin{array}{r}\text { Service is any activity or benefit provided by one party to another party which is basically intangible } \\
\text { and does not lead to any ownership. }\end{array}$ \\
\hline
\end{tabular}

Service quality: According to (Garvin.1989) cited by (Poku,et al., 2013) being able to satisfy given needs reflects the value (or quality) of the product or service to the customer, including the economic value, safety, reliability, and maintainability.

\begin{tabular}{cc}
\hline Authors & Definition \\
\hline $\begin{array}{c}\text { Oliver, R. L. } 1980 \\
\begin{array}{c}\text { Gronroos, C., } \\
1984\end{array}\end{array}$ & $\begin{array}{c}\text { Service quality can be defined as global judgment for the received service that offered to the customer by } \\
\text { producer }\end{array}$ \\
$\begin{array}{c}\text { Parasuraman, et } \\
\text { al. (1985.1988) }\end{array}$ & $\begin{array}{r}\text { Service quality is content ten keys: Reliability, Responsiveness, Competence, Access, Courtesy, Commu- } \\
\text { nication, Credibility, Security, Understanding, Tangibles. }\end{array}$ \\
\hline
\end{tabular}

Customer loyalty: customers may remain loyal due to high switching barriers or the lack of real substitutes, while others will continue to be loyal because they are satisfied with the services provided (Lam, R. \& Burton, S. ,2006).

\begin{tabular}{cl}
\hline \multicolumn{1}{c}{ Authors } & \multicolumn{1}{c}{ Definition } \\
\hline Bowen \& Shoemaker, $1998 \begin{array}{l}\text { Customer loyalty is return or continues to use the same product or other products of the same } \\
\text { organization. }\end{array}$ \\
\hline Baldinger\& Rubinson, $1996 \begin{array}{l}\text { Customer loyalties that are not easily swayed by price inducement from competitors, and they } \\
\text { usually purchase more than those less loyal customers. }\end{array}$ \\
\hline Benntt \& Leonard, 2000 & Customer loyalty is a replicate procurement process resulting from preference. \\
\hline Kotler, 2003 & $\begin{array}{l}\text { Customer loyalty is a customer's measure and his desire in exchange participation in organiza- } \\
\text { tion interactive activities. }\end{array}$ \\
\hline \hline
\end{tabular}

Ziethmail, Berry, Parasuraman, (1996) there are a set of attempts that aimed to determine most important dimensions as follows: 
1- The intention of re-dealing which reflect frequent dealing with organization.

2- Non price sensitivity through willingness by customer to pay higher prices.

3- Word of mouth communication.

4- Complaint behavior.

\section{Research Problem and Questions}

Problem Statement: The Kurdistan region has huge potential of tourist destination and hotels to attract tourists both domestic and international, however, despite the region's many attractions the tourism activity in the Kurdistan Region is confronted by a number of challenges because of the limited services provided by the hotels and high price of accommodations in the five star hotels. The hotels also has weak supporting services, while there is much needed improvement to be made to hotels and entertainment services. For explain and analysis the role of hotel quality services of attracting tourist and achieving their loyalty; this study formulated two of questions relevant to the study:

1- What are the factors influence attracting tourist to hotel sector in Kurdistan region of Iraq?

2- What are the specific service qualitiy attributes that influence attracting tourist and achieving their loyalty in hotel sector in Kurdistan region of Iraq?

\section{Research Objectives}

This study aims to achieve the following specific objectives:

1- Determine and analyze the impact of service quality on attracting tourist in the Kurdistan five stars hotels.

2- Determine the level of relationship between service quality and tourist loyalty in the Kurdistan five stars hotels.

\section{Research Hypotheses}

Null hypothesis have been formulated, and the hypothesis are:

- $\mathrm{H}_{0}$ : There is a negative correlation between service quality and attracting tourists in the Kurdistan five stars hotels.

- $\quad \mathrm{H}_{1}$ : There is a positive correlation between service quality and attracting tourists in the Kurdistan five stars hotels.

- $\quad \mathrm{H}_{0}$ : There is a negative correlation between service quality and tourist loyalty in the Kurdistan five stars hotels.

- $\quad \mathrm{H}_{1}$ : There is a positive correlation between service quality and tourist loyalty in the Kurdistan five stars hotels.

\section{Research Justifications}

The Kurdistan region of Iraq can become an attractive destination for domestic and international tourists when provide high level of service in hotel in general and in five stars hotel specially. In addition, current study highlight and explain how service quality dimensions has an important role of attracting tourists and achieve their loyalty, as well as, this study provide some suggestion for five-star hotel manager to increase tourist's loyalty in hotels and continuous improvement in those services level.

\section{Structure of the Research}

The research organized as follow section 1 include introduction of the study, whereas section 2 discusses literature review and theoretical framework, while section 3 affords literature review. Section 4 presents the methodology and data collection. Section 5 provides the main results and discussions. Section 6 affords the main conclusion and recommendations, Limitation of the study and Future research are provided. 


\section{Research Design}

Current section explains the data collection and the study sample. The major parts of this section are the variables, population and sample, data collection as following:

1- Study Variables and Study Models: This study is based on the descriptive analytical method (DAM), and the study model was basis on the previous studies and literature review which relate to subject of the study. Moreover, the service quality (independent variable) and tourist loyalty (dependent variable).

2- Population and Study Sample: The number of five stars hotels in Kurdistan(20 hotels), but the target population selected for this study consists of all five- star hotels (Shari jwan, Ramada, High creast and Taitanic) in Sulaimani province - Kurdistan region/Iraq. While the study sample includes 70 guests who stayed in all five star hotels during the period (25 Nov. to 25 Dec. 2016), and 70 questionnaires were distributed on guests, but only (62 response) was recovered and used as a basic of study.

3- Data Collection Procedures: After some appropriate adjustments, current study depends on scales that have been used in previous study (Parasuraman, Berry,Ziethmail, 1988 and 1996) and (Al- Rousan and Mohammad, 2010). Questionnaire was used as an instrument for collecting primary data, which has been distributed to tourist's five-star hotels in Sulaimani province.

\section{Data Analysis:}

The results of study were carried out through applying various statistical techniques such as factor analysis and multiple regressions.

\section{1- Respondents Profile}

Preliminary data was collected via field survey from 62 guests, Respondents are asked to give answers of the questions related to their personal information. The profile of a respondent as shown in table (1).

The profile of a respondent shows the majority of the respondents are male, (44\%) of them are in the age range of $45-55$ years, (68 \%) are married, $47 \%$ their profession is business, the majority are graduated, (42\%) of guests come from middle and south of Iraq, while (32\%) from out of Iraq and about length of stay, the twice a year was highest level and equal to $(42 \%)$.

\section{2- Scale Reliability}

To determine instrument reliability ${ }^{1 *}$ Cronbach's alpha coefficient was used to check the internal consistency of the statements used in questionnaire preparation. Therefore Cronbach's alpha coefficient has been calculated for all used scales.
Table 1. Respondent Demographic Profile

\begin{tabular}{|c|c|c|c|}
\hline Information & Item & Number & Percentage (\%) \\
\hline \multirow[t]{2}{*}{ Gender } & Male & 38 & 61 \\
\hline & Female & 24 & 39 \\
\hline \multirow[t]{4}{*}{ Age } & $25-34$ & 9 & 14 \\
\hline & $35-44$ & 19 & 31 \\
\hline & $45-54$ & 27 & 44 \\
\hline & $55-64$ & 7 & 11 \\
\hline \multirow{3}{*}{$\begin{array}{c}\text { Marital } \\
\text { status }\end{array}$} & Married & 42 & 68 \\
\hline & Single & 16 & 26 \\
\hline & Others & 4 & 6 \\
\hline \multirow[t]{4}{*}{ Profession } & Business & 29 & 47 \\
\hline & Service & 26 & 42 \\
\hline & Retired & 4 & 6 \\
\hline & Others & 3 & 5 \\
\hline \multirow{6}{*}{ 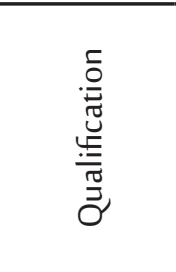 } & Elementary & 3 & 5 \\
\hline & junior high school & 3 & 5 \\
\hline & high school & 5 & 8 \\
\hline & under graduate & 11 & 18 \\
\hline & Graduate & 38 & 61 \\
\hline & post graduate & 2 & 3 \\
\hline \multirow[t]{3}{*}{ Come from } & north of Iraq & 16 & 26 \\
\hline & middle and south of Iraq & 26 & 42 \\
\hline & Out Iraq & 20 & 32 \\
\hline \multirow{5}{*}{$\begin{array}{l}\text { Length of } \\
\text { stay }\end{array}$} & less than once a year & 10 & 16 \\
\hline & once a year & 3 & 5 \\
\hline & twice a year & 23 & 37 \\
\hline & more than twice a year & 26 & 42 \\
\hline & Total & 62 & 100 \\
\hline
\end{tabular}

1 - Scale validity means that questionnaire has to measure aspects that have been developed to measure, but scale reliability means the extent of obtaining the same results in case of research repeating in similar circumstances and using the same scale. 
The questionnaire included six statements to measure tangibility, five statements for reliability, four statements for responsiveness and four for assurance and finally three for empathy. This means that the original questionnaire included (22) statements which has been approved by (Parasuraman. et.al.1988) and (Al- Rousan and Mohammad, 2010) to measure service quality through (SERVPERF) scale.

\section{Results}

Testing for reliability and factor analysis for service quality dimensions necessitates and important. The results of the factor analysis and reliability for service quality dimensions are reported below.

Overall, as shown in Table (3), the results indicate the sample adequacy for the use of factor analysis to clarify the factor structure, and all statements had included high downloads that exceed (0.5).

Table 3. Result of Factor Analysis and Reliability for Service Quality Dimensions

\begin{tabular}{|c|c|c|c|}
\hline Service Quality Dimensions & \multicolumn{3}{|c|}{ Factor Load } \\
\hline \multicolumn{4}{|l|}{ Tangibility } \\
\hline Furniture in this hotel is modern and comfortable & \multicolumn{3}{|l|}{.968} \\
\hline The interior and exterior decoration in this hotel is quite appealing & \multicolumn{3}{|l|}{.981} \\
\hline The employees have neat appearances & \multicolumn{3}{|l|}{.955} \\
\hline The hotel facilities are up-to-date & \multicolumn{3}{|l|}{.904} \\
\hline The brochures and pamphlets are visually presented & \multicolumn{3}{|l|}{.811} \\
\hline The hotel is clean & \multicolumn{3}{|l|}{.847} \\
\hline \multicolumn{4}{|l|}{ Reliability } \\
\hline The front-desk employee accurately verified the reservation requests & \multicolumn{3}{|c|}{.739} \\
\hline The time it took to check in or check out is not too long & \multicolumn{3}{|c|}{.669} \\
\hline The reservation system (e.g., telephone or internet reservation)is easy to use & \multicolumn{3}{|c|}{.803} \\
\hline Transport facilities are available & \multicolumn{3}{|c|}{.655} \\
\hline The employees provide error-free records & \multicolumn{3}{|c|}{.673} \\
\hline \multicolumn{4}{|l|}{ Responsiveness } \\
\hline The employees are courteous & \multicolumn{3}{|c|}{.754} \\
\hline The employees gave us special attention & \multicolumn{3}{|c|}{.764} \\
\hline The employees adapted services to our needs & \multicolumn{3}{|c|}{$\begin{array}{r}.796 \\
\end{array}$} \\
\hline The staff are willing to help guests & \multicolumn{3}{|c|}{ Table 2. CronbachAlp $\not{4} 4$ coefficient } \\
\hline Assurance & \multicolumn{3}{|c|}{ for Flements } \\
\hline The staff in the hotel are polite & \multicolumn{3}{|c|}{.762} \\
\hline The staff imparted confidence to the guests & \multicolumn{3}{|c|}{ Type of Variables Number of $\overline{\text {.9Bonbach's }}$} \\
\hline The staff are friendly & \multicolumn{3}{|c|}{ questions 75 glpha } \\
\hline The staff had sufficient support from the hotel to do their jobs & \multicolumn{3}{|c|}{ 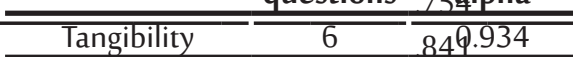 } \\
\hline Empathy & \multicolumn{3}{|c|}{ Reliably $\frac{5}{0.891}$} \\
\hline The employees quickly apologized when service mistakes are made & Responsiveness & 4 & 0.899881 \\
\hline The employees listened carefully when you complain & Assurances & 4 & 0.90141 \\
\hline Employees understand the customer's requirements & Empathy & 3 & $0.90 \Phi 08$ \\
\hline $\mathrm{KMO}$ & Loyalti11 0. & .7580 .836 & J.797.90В98 \\
\hline Eigen value & Note: All balleses & 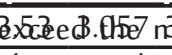 & 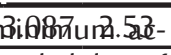 \\
\hline
\end{tabular}

Moreover, testing for reliability and factor analysis for tourist loyalty dimensions necessitates and important Factor analysis was used to convert and divide the items to several factors. However, some items sometimes represent the same idea, thus these can be omitted if they are redundant or unnecessary. Also the results of the factor analysis and reliability for tourist loyalty dimensions are shown in Table (4). 
From table (4) shows the Factor analysis results for Loyalty Dimensions at significance levels and this indicates that (KMO) was $>0.5$ ,Eigen value $>1$ and Factor load $>$ 0.5 . Bartlett test significant value was (sig $=0.000$ ) as indicated in Table (4). The empirical results for Factor analysis test and reliability enable the estimated model.

\section{1- Descriptive Statistics}

This part indicates the level of agreeableness and disagreeableness of the respondents by seeing the value of mean. The value of the Mean and Std. Deviation are presented in Table (5).

Table 5. Result of Mean and Std. Deviation for Service Quality

\begin{tabular}{|c|c|c|}
\hline Statement & Mean & Std. Deviation \\
\hline \multicolumn{3}{|l|}{ Service Quality Dimensions } \\
\hline \multicolumn{3}{|l|}{ Tangibility } \\
\hline Furniture in this hotel is modern and comfortable & 4.9 & 0.39 \\
\hline The interior and exterior decoration in this hotel is quite appealing & 4.88 & 0.44 \\
\hline The employees have neat appearances & 3.91 & 0.32 \\
\hline The hotel facilities are up-to-date & 3.95 & 0.52 \\
\hline The brochures and pamphlets are visually presented & 4.35 & 0.74 \\
\hline The hotel is clean & 3.93 & 0.56 \\
\hline \multicolumn{3}{|l|}{ Reliability } \\
\hline The front-desk employee accurately verified the reservation requests & 4.33 & 0.69 \\
\hline The time it took to check in or check out is not too long & 3.72 & 0.89 \\
\hline The reservation system (e.g., telephone or internet reservation)is easy to use & 4.3 & 0.75 \\
\hline Transport facilities are available & 4.59 & 0.61 \\
\hline The employees provide error-free records & 4.12 & 0.81 \\
\hline \multicolumn{3}{|l|}{ Responsiveness } \\
\hline The employees are courteous & 4.5 & 0.74 \\
\hline The employees gave us special attention & 4.35 & 0.79 \\
\hline The employees adapted services to our needs & 4.45 & 0.78 \\
\hline The staff are willing to help guests & 4.41 & 0.73 \\
\hline \multicolumn{3}{|l|}{ Assurance } \\
\hline The staff in the hotel are polite & 4.45 & 0.80 \\
\hline The staff imparted confidence to the guests & 4.25 & 0.82 \\
\hline The staff are friendly & 4.27 & 0.83 \\
\hline The staff had sufficient support from the hotel to do their jobs & 4.51 & 0.84 \\
\hline \multicolumn{3}{|l|}{ Empathy } \\
\hline The employees quickly apologized when service mistakes are made & 4.51 & 0.62 \\
\hline The employees listened carefully when you complain & 4.38 & 0.61 \\
\hline Employees understand the customer's requirements & 4.56 & 0.61 \\
\hline
\end{tabular}

Table 4. Result of Factor Analysis and Reliability for Customer Loyalty Dimensions

\begin{tabular}{lc}
\hline \multicolumn{1}{c}{ The Loyalty Dimensions } & Factor Load \\
\hline I would recommend this hotel to other people & .834 \\
\hline I would like to stay in this hotel next time & .849 \\
\hline I would like repurchase many services in this hotel & .889 \\
\hline I would encourage friends and relatives to visit this hotel & .859 \\
\hline I consider the performance in this hotel strong & .892 \\
\hline I would consider this hotel as my first choice when I need service & .898 \\
\hline I intend to continue using this hotel & .845 \\
\hline KMO & 0.925 \\
\hline Eigen value & 6.066 \\
\hline Note: The original questionnaire included only seven statements to measure \\
the tourist loyalty.
\end{tabular}
Source: Prepared by researchers based on SPSS. 
Table(6) indicates that the mean of all statements goes toward (4) which shows that majority of the respondent surveyed are agree on the statement that hotel service quality has significant impact on all tourist loyalty Dimensions .

\section{2- Pearson Correlation: Current} study applying (Pearson Correlation Checking) for testing study hypotheses: $\mathrm{H}_{0}$ "there is a negative correlation of (Tangibility, Reliability, Responsiveness, Assurance, Empathy) on (tourist's loyalty) in five star hotels in Sulaimani province" and $\mathrm{H}_{1}$ "there is a positive correlation of (Tangibility, Reliability, Responsiveness, Assurance, Empathy) on (tourist's loyalty) in five stars hotels in Sulaimani province". Likewise, for answering study question: "What is the specific service quality attributes that influence attracting tourists and achieving their loyalty in five- star hotels in Sulaimani province- Kurdistan region/ Iraq? Analysis obtained for the five intervals scaled variables in the table (7).

Table (7) indicates that the p-value for all statements is 0.000 , which is less than 0.05 , therefore, as a whole, we reject the null hypothesis $\left(\mathrm{H}_{0}\right)$ and accept $\left(\mathrm{H}_{1}\right)$. Thus, concluded that there are a strong positive relationship between quality service dimensions (Tangibles, Reliability, Responsiveness, Assurance, Empathy) and tourist loyalty in the five star hotels in Sulaimani province. Such result is a line with the previous study (AL-Aali .2011; AL-Bassam, 2013 ; Bin Sau'd Imam Muhammad, 2013).

3- Regression Analysis: Model of the service quality and tourist Loyalty (Local and International tourists) in five star hotels in Sulaimani province. The results of regression model are presented in Table (8).

Table (8) clearly indicates that the model, as a whole, is a significant fit to the data, because $R^{2}$ is close to Adjusted $\mathrm{R}^{2}$ as well as is too high (0.85) .The regression model interpretation ability for all service quality dimensions represented in $\left(\mathrm{R}^{2}\right)$ coefficient was 0.85 indicating that $85 \%$ of changes in tourist loyalty level are interpreted by service quality dimensions. Moreover, as shown in table(8), and based on the (t- test and p-value) all statements are significant at the $5 \%$ significance level, which is the result of study is consistent
Table 7. Result of Pearson Correlation Coefficient

\begin{tabular}{cccc}
\hline Statement & $\begin{array}{c}\text { Pearson } \\
\text { correlation }(\mathbf{r})\end{array}$ & $\begin{array}{c}\text { Significant Decision } \\
\text { level }\end{array}$ & \\
\hline Tangibility & 0.79 & 0.000 & RejectH0 \\
\hline Reliability & 0.78 & 0.000 & Reject H0 \\
\hline Responsiveness & 0.84 & 0.000 & Reject H0 \\
\hline Assurance & 0.87 & 0.000 & Reject H0 \\
\hline Empathy & 0.51 & 0.000 & Reject H0 \\
\hline
\end{tabular}

Note: the following interpretation of r-value .This value will indicate the strength of the relationship between two variables.

A: $r=.10$ to .29 or $r=-.10$ to -.29 weak

B: $r=.30$ to .49 or $r=-.30$ to -.49 Medium

C: $r=.50$ to 1.0 or $r=-.50$ to -1.0 strong

Note: In the Pearson correlation analysis the number of variables (dependent and independent) is two, and the number of sample size $(\mathrm{N})$ is 62 .

Note: The significant level is 0.05 (p_0.05).

Source: Prepared by researchers based on SPSS.

Table 8. Regression Result of Hotel Service Quality and Customer Loyalty

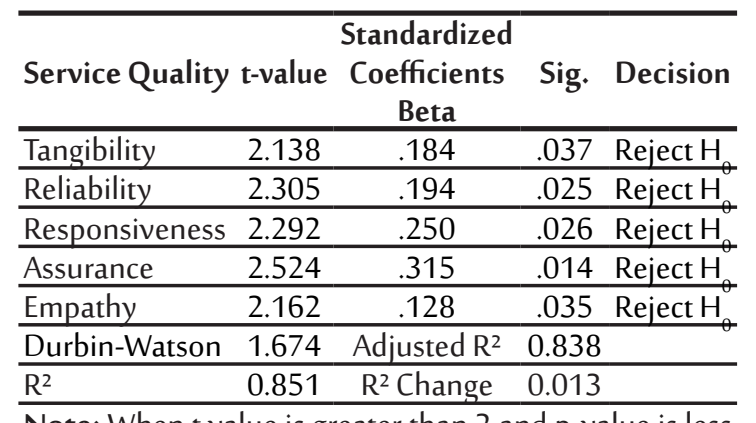

Note: When $t$ value is greater than 2 and $p$-value is less than 0.05, null hypothesis is rejected.

Note: Reject all $\left(\mathrm{H}_{2}\right)$ and Accept all $\left(\mathrm{H}_{4}\right)$.

Source: Prepared by researchers based on SPSS. 
with theoretical and previous studies (AL-Aali, 2011; AL-Bassam, 2013; Bin Sau'd Imam Muhammad, 2013). Likewise, interpretation of the coefficient of model estimation as follows:

- Tangibility $\left(\mathbf{B}_{1}\right)$ : The value of regression coefficient of tangibility is 0.148 with p-value of 0.037 , which indicate that the increase in tangibility by one percent led to increase tourist's loyalty by 0.184 , keeping the other variable constant.

- Reliability $\left(\mathbf{B}_{2}\right)$ : The regression coefficient for reliability is 0.149 with $p$-value 0.025 , which indicate that one percent led to increase tourist's loyalty by 0.184 , holding other variables constant.

- Responsiveness $\left(B_{3}\right)$ : Holding other variables constant, the regression coefficient of responsiveness is 0.25 with p-value of 0.026 , which indicate that the increase in responsiveness by one percent led to increase tourist's loyalty by 0.25 , keeping the other variable constant.

- Assurance $\left(B_{4}\right)$ : The value of regression coefficient of assurance is 0.315 with p-value of 0.014 , which indicate that the increase in assurance by one percent led to increase tourist's loyalty by 0.315 , holding other variables constant.

- Empathy ( $\mathbf{B}_{5}$ ): keeping the other variable constant, the value of regression coefficient of empathy is 0.128 with p-value of 0.035 , which indicate that the increase in empathy by one percent led to increase tourist's loyalty by 0.128 , keeping the other variable constant.

From above interpretation, we can say all variables (statements) completely consistent with the Service Quality and tourist loyalty theories, and all results basically the same finding which has previous study.

\section{Conclusion and Recommendation}

Monitoring tourist loyalty has become an important focus for all managers in the hotel industry. Failure to recognize the power of tourist satisfaction, especially their emotions, could affect the power of tourist loyalty. This study identified five service quality dimensions which are (tangibility, reliability, responsiveness; assurance and empathy), to evaluate service quality of five star hotel. The main objective of the study is to examine the impact of service quality on attracting tourists and tourist loyalty in the five- stars hotel in Sulaimani province - Kurdistan region/ Iraq. This study is based on the descriptive analytical method (DAM), and the study model was basis on the previous studies and literature review which relate to subject of the study. The 70 questionnaires were distributed on 70 tourists who stayed in five star hotel. Based on study hypotheses and examine of the Pearson correlation indicated strong positive significant relationship among service quality dimensions (Tangibles, Reliability, Responsiveness, Assurance, and Empathy) and tourist attract and tourist loyalty. Besides, the findings of this study indicate that the most important factor in hotel service quality evaluation was assurance, followed by, responsiveness. Based on the results the researchers recommend the following:

1- The government should seriously consider tourism activities with sufficient weight to re-plan the tourism strategy in the Kurdistan region and adopt new policies on the behavior of domestic and international tourists and how to attract new tourists to the Kurdistan Region.

2- Should hotel managers having knowledge about the dimension of service quality would help managers meet the challenge of improving service quality in the hotel industry to attracting more tourists (especially international one), and investigate loyalty and satisfaction for tourists by set plan in the competitive hospitality market environment.

3- To attract more tourists to the Kurdistan region, the hotel management should provide more services. Likewise, the tourism services need more promotion to reduce pressure on tourist budgets, both domestic and international. The diversity of tourism products and the quality of services are also vital. 
4- Should hotel managers develop its service quality, as well as including other factors affecting tourist loyalty, such as a study of the impact of price that affect attracting tourists and achieving their loyalty.

5- To provide services that may increase tourist's loyalty in hotels and continuous improvement in those services level through attending the necessary employee training courses related to tourist service.

6- Further study is very essential in the matter. Research could be broadened to include other dimension of service quality in five stars hotel as well as other factors that affect tourist attracting. 


\section{References}

Ahmed, Y. A. (2014). "Role of the Tourism Sector in the Iraqi Economy", Unpublished PhD Thesis, University Putra Malaysia, Malaysia.

- $\quad$ Akbaba, A. (2006). “Measuring Service Quality in the Hotel Industry: A Study in a Business Hotel in Turkey", Hospitality Management, 25, 170-192 www.elsevier.com/locate/ijhosman

- $\quad$ Akbar, M. M. and Parvez, N. (2009). "Impact of Service Quality, Trust and Customer Satisfaction on Customer Loyalty", ABAC Journal, pp. 24-38.

- $\quad$ Al-Rousan, M. R. \& Mohamed, B. (2010). “Customer Loyalty and the Impacts of sService Quality: The Case of Five Star Hotels in Jordan", International Journal of Human and Social Sciences, 5, (13), 886-892.

- $\quad$ Al. Bostanji, G. M. and Bin Sau'd, I. M. (2013). "The Impact of Service Quality on Customers Loyalty: A Study on Five Stars Hotel's Customers in Riyadh, KSA. European Journal of Business and Management, pakacademicsearch. com/.../230-240\%20Vol\%205,\%20No\%2031\%2

- Al Bassam, T. A. (2013). "A Model for Measuring Service Quality in Internet-Based Services", Doctoral Dissertation, Brunel University, Uxbridge, Middlesex, UK).

- Babakus, E. \& Boller, G. W. (1992). "An Empirical Assessment of the SERVQUAL Scale", Journal of Business Research, 24 (3), pp. 253-268.

- Bagdare, S. (2016). "Effect of Employees on Customers Loyalty in Hotel Industry", Imperial Journal of Interdisciplinary Research, 2 (5).

- Baldinger, A. L. and Rubinson, J. (1996). "Brand Loyalty: The Link between Attitude and Behavior", Journal of Advertizing Research, 36, (6), 22-35.

- Benntt, R. and Leonard, V. (2000) Trust Commitment and Attitudinal Brand Loyalty Key Constructs in Business-to Business Relationships, ANZMAC. Visinary Marketing for the $21^{\text {st }}$ Century, pp. 88-92.

- Boulding, W.; Kalra, A.; Staelin, R. and Zeithaml, V. A. (1993). "A Dynamic Process Model of Service Quality: From Expectations to Behavioral Intentions", Journal of Marketing Research, pp. 7-27.

- $\quad$ Bowen, J. T. \& Shoemaker, S. (1998). “Loyalty: A Strategic Commitment", The Cornell Hotel and Restaurant Administration Quarterly, 39 (1), pp. 12-25.

- $\quad$ Burns, P. M. and Holden, A. (1995). Tourism a New Perspective. Prentice Hall, New York, NY.

- Carman, J. (1990). Consumer Perceptions of Service Quality: An Assessment of the SERVQUAL Dimensions", Journal of Retailing, 66 (1), 33.

- Carman, J. M. (1990). “Consumer Perceptions of Service Quality: An Assessment", Journal of Retailing, 66(1), 33.

- Cronin, J. Jr. and Taylor, S. A. (1994). "SERVPERF versus SERVQUAL; Reconciling Performance-Based and Perception-Minus-Expectations: Measurement of Service Quality", Journal of Marketing, pp. 125-31.

- Czepiel, John A. (1990). "Managing Relationships with Customers: A differentiation Philosophy of Marketing," in Service Management Effectiveness, D. E. Bowen , R. B. Chase, and T. G. Cummings, eds. San Francisco: Jossey-Bass, 299-323.

- Ekinci, Y. (2003). "An Investigation of the Determinants of Customer Satisfaction", Tourism Analysis, 8, (2), 193-196. 
Geronikolas, N. (2012). Customer Defects in the Hotel Industry: The Five (5) Most Common Factors Driving Business Away. USA: Hub Pages Inc. Retrieved, March 26, 2015, from: http://nikgeronikolas.hubpages.com/hub/Customer-Defects-in-the-Hotel-IndustryThe-Five-5-most-important-factors-driving-business-away.

- Goeldner, C. R. and Ritchie, J. R. B. (2003). Tourism: Principles, Practices, Philosophies. $9^{\text {th }}$ ed. Wiley, Hoboken.

Gronroos, C. (1984). "A Service Quality Model and its Marketing Implications", European Journal of Marketing, pp. 36-44.

- Gronroos, C. (2000). Service Management and Marketing. John Wiley \& Sons Ltd. Geronikolas. Hosseini, R. S., Zainal, A. and Sumarjan, N. (2015). The Effects of Service Performance of Hotel Customers on Quality of Experience and Brand Loyalty in Iran. Procedia-Social and Behavioral Sciences, 201, 156-164.

- Hub Pages Inc. Grönroos, C. (2000). “Creating a Relationship Dialogue: Communication, Interaction and Value", The Marketing Review, 1 (1), 5-14.

- Jahanshahi, A. A.; Gashti, M. A. H.; Mirdamadi, S. A.; Nawaser, K. and Khaksar, S. M. S. (2011). "Study the eEffects of cCustomer Service and Product Quality on Customer Satisfaction and loyalty", International Journal of Humanities and Social Science, 1 (7), 253-260.

- $\quad$ Kheng, L. L.; Mahamad, O.; Ramayah, T. and Mosahab, R. (2010). “The ilmpact of Service Quality on Customer Loyalty: A Study of Banks in Penang, Malaysia", International Journal of Marketing studies, 2, (2), 57-66.

- Khraim, H. S. (2013). "Airline Image and Service Quality Effects on Traveling Customers' Behavioral Intentions in Jordan", European Journal of Business and Management, 5 (22), 20-34.

- $\quad$ Kofi, P. M. Z. and Riajara, S. (2013). "Impact of Service Quality on Customer Loyalty in the Hotel Industry: An Empirical Study from Ghana", International Review of Management and Business Research, Vol. 2, Issue.2.

- $\quad$ Kotler, P. and Armstrong, G. (2004). Principles of Marketing. $10^{\text {th }}$ ed. Person Education Inc. Upper Saddle River, New Jersey.

- $\quad$ Kotler, Philip. (2003). Marketing Insights from A to z 80 Concepts Every Manager Needs to Know. New Jersey.

- $\quad$ Lam, R. and Burton, S. (2006). "SME Banking Loyalty and Disloyalty: A Qualitative Study in Hong Kong", International Journal of Bank Marketing, 24 (1), 37-52.

- Leon-Ledesma, Miguel A., ed. (2007) The Asian Development Outlook 2007: Growth amid change. Asian Development Outlook. Asian Development Bank, China.

- $\quad$ Lovelock, C. and Wirtz, J. (2004). Services Marketing: People, Technology, Strategy. ${ }^{\text {th }}$ ed. PrenticeHall.www.kau.edu.sa/GetFile.aspx?...Service\%20MKG\%20Lovelock\%20

- Mosahab, R.; Mahamad, O. and Ramayah, T. (2010). “Service Quality, Customer Satisfaction and Loyalty: A Test of Mediation", International Business Research, 3 (4), 72.

- Nsour, I. A. (2013). “Examine the Relationship between Internal Marketing \& Internal Service Quality in Saudi Public Hospitals", Hospitals, 3 (19).

- Oliver, R. L. (1980). "A Cognitive Model of the Antecedents and Consequences of Satisfaction Decisions", Journal of Marketing Research, 460-469.

- Osayawe, Ehigie, B. (2006). “Correlates of Customer Loyalty to Their Bank: A Case Study in Nigeria. InternationalJournal of Bank Marketing, 24 (7), 494-508. 
- $\quad$ Panda, T. K. (2003). Creating Customer Lifetime Value Through Effective CRM in Financial Services Industry", Journal of Services Research, Vol. 2, No. 2, 2003, pp. 157-171.

- $\quad$ Parasuraman, A.; Zeithaml, V. A., Malhotra, and Arvind. (2005). “E-S-QUAL: A Multiple-Item Scale for Assessing Electronic Service Quality", Journal of Service Research, 7 (3), 213-233.

- Parasuraman, A.; Zeithaml, V. A. and Berry, L. L. (1985). “A Conceptual Model of Service Quality and its Implications for Future Research", The Journal of Marketing, 41-50.

- Parasuraman A.; Ziethmail, V. and Berry L. (1988) "SERVQUAL: A Multiple-item sScale for Measuring Consumer Perception of Service Quality", Journal of Retailing, Vol. 64, No.1, pp. $12-49$.

- $\quad$ Poku, K.; Zakari, M. and Soali, A. (2013). “Impact of Service Quality on Customer Loyalty in the Hotel Industry: An Empirical Study from Ghana", International Review of Management and Business Research, 2, (2), 600-609.

- $\quad$ Saleem, H. and Raja, N. S. (2014). “The Impact of Service Quality on Customer Satisfaction, Customer Loyalty and Brand Image: Evidence from Hotel Industry of Pakistan", Middle-East Journal of Scientific Research, 19(5), 706-711.

- Siddiqi, K. O. (2011). “Interrelations between Service Quality Attributes: Customer Satisfaction and Customer Loyalty in the Retail Banking Sector in Bangladesh", International Journal of Business and Management. Vol. 6, No. 3, 12-36.

- $\quad$ Spreng, R. A.; Mackenzie, S. B. and Olshavsky, R. W. (1996). "Are Examination of the Determinants of Consumer Satisfaction", Journal of Marketing. Vol. 60, March, 15-32.

- Weaver, D. and Oppermann, M. (2000). Tourism Management. John Wiley \& Sons, New York, NY.

- WTO. (2003). World Tourism Organization, available at: www.world-tourism.org.

- Zeithaml, V.; Berry, L. and Parasuraman A. (1996) “The Behavioral Consequences of Service Quality", Journal of Marketing, pp. 31-45.

- Zeithaml, V. A. (2000). "Service Quality, Profitability and the Economic Worth of Customers: What We Know and What We Need to Learn", Journal of the Academy of Marketing Science, 28, (1), 67-85.

- $\quad$ Zeithaml, V. A.; Wilson, A. and Bitner, M. J. (2008). Services Marketing. $4^{\text {th }}$ ed. New Delhi: The McGraw-Hill Companies. 